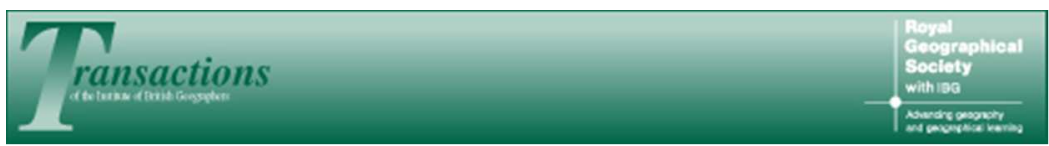

\title{
Living Precariously: Property Guardianship and the Flexible City
}

\begin{tabular}{|c|c|}
\hline Journal: & Transactions of the Institute of British Geographers \\
\hline Manuscript ID & TIBG-RP-Dec-2015-0136.R2 \\
\hline Manuscript Type: & Regular Paper \\
\hline Keywords: & $\begin{array}{l}\text { precarious geographies, property guardianship, London, precarity, } \\
\text { flexibility }\end{array}$ \\
\hline Abstract: & $\begin{array}{l}\text { In this paper we examine the precarious everyday geographies of property } \\
\text { guardianship in the United Kingdom. Temporary property guardianship is a } \\
\text { relatively new form of insecure urban dwelling existing in the grey area } \\
\text { between informal occupation, the security industry and housing. Young } \\
\text { individuals, usually in precarious employment, apply to intermediary } \\
\text { companies to become temporary 'guardians' in metropolitan centres, most } \\
\text { notably in London. The scheme allows guardians to pay below market rent } \\
\text { to live in unusual locations while 'performing' live-in security arrangements } \\
\text { that are not considered as a form of 'work'. The experiences of becoming } \\
\text { and living as a property guardian can be ambivalent and contradictory: } \\
\text { guardians express economic and social advantages to being temporary, } \\
\text { while also exposing underlying anxieties with 'flexible living'. In this paper } \\
\text { we offer a detailed description of the various practices of property } \\
\text { guardianship and how they must be understood on the one hand, in light of } \\
\text { recent geographical scholarship on housing insecurity and, on the other } \\
\text { hand, as an example of a precarious subjectivity that has become } \\
\text { normalised in recent decades in cities of the global North. Drawing on in- } \\
\text { depth interviews with long-term property guardians in London, we unpack } \\
\text { the narratives and rationales of university-educated and highly skilled } \\
\text { individuals for whom the city is a site of intensified insecurity and flexible } \\
\text { negotiations. In the end, we conclude that the form of permanent } \\
\text { temporariness experienced by property guardians needs to be understood } \\
\text { as a symptom of wider dynamics of work and life precarisation in urban } \\
\text { centers and argue that it is imperative to extend recent geographical } \\
\text { debates around work and life insecurity to include new housing practices } \\
\text { and their role in co-constituting urban precarity. }\end{array}$ \\
\hline
\end{tabular}




\section{Living Precariously: Property Guardianship and the Flexible City}

Join the many professionals, key workers and mature/post graduate students across the UK who have chosen the new affordable alternative to renting.

(AdHoc 2015)

As a nurse, living for Camelot means I can afford to live in London. My colleagues really envy me; so much space for very little money.

(Camelot 2014)

Over the last fifteen years, a number of private companies have been founded in the UK and elsewhere in Europe to operate as intermediaries in the area between security and housing through the mechanism of 'property guardians' or 'live-in guardians'. The role of these businesses has been to introduce and promote schemes that provide low-cost security of vacant buildings and protect them from squatting and vandalism. At the same time, the schemes enable individuals to find temporary accommodation in properties otherwise considered unsuitable for rent, either because of their class of use (for example, warehouses and other commercial properties) or because of pending demolition or redevelopment plans. In this way low-income but 'flexible' individuals such as students and precarious, part-time and self-employed workers, especially in the creative sectors, are able to live inexpensively in both unusual sites and central urban locations.

In the UK national media, property guardianship (hereafter PG) has been variously described as a solution to the lack of housing affordability (England 2015; Meyer 2013); as a form of adventurous living (Norwood 2010) and as a viable security option for owners of dilapidated properties, particularly in contexts of urban regeneration (Wainwright 2014). Despite widespread media coverage there has, however, been limited research on the topic. This paper 
is one of the first academic pieces dedicated to PG in the $\mathrm{UK}^{1}$ and, as such, it seeks to describe as well as analyse PG as an emergent form of insecure low-cost housing. It focuses, in particular, on the experience and understanding of guardianship by guardians themselves, but also asks wider questions about the meaning and instrumentalisation of 'guarding' as a form of security, the preservation of value and neoliberal experiences and expectations of housing and work. How does PG function as a socio-economic-legal mechanism for shortterm occupation and tenure? Who are the applicants, what are their rationales for becoming guardians and what kind of spaces do they tend to occupy? What is the relationship between the everyday geographies of PG and the increasingly precarious nature of contemporary city life? And what do these geographies reveal about the city as a site of intensified precarity?

In order to answer these questions, this paper offers a thick description of the various practices of PG and how they must be understood, on the one hand, in light of recent geographical scholarship on housing insecurity (Dorling 2014; Hodkinson 2012) and, on the other hand, as another example of the precarity that has emerged in recent decades in the cities of the global North (see McDowell, Rootham and Hardgrove 2014; Molé 2012; Ross, 2009; Standing 2014; Strauss and Meehan 2015; Weeks 2011). By examining the conditions and experiences of property guardians we seek, in this paper, to respond to recent calls for the development of new conceptual tools to address the challenges posed by new austerity urbanisms and the precarious geographies that they produce (Lewis et al. 2015; Peck 2012; Roy 2011; author 2015a; Waite 2009). The paper aims to extend recent debates in this journal, and in geography more generally, around work and life insecurity and the constitutive sociospatial precariousness of our present conjuncture (Noxolo et al. 2014; see Ettlinger 2007;

\footnotetext{
${ }^{1}$ With the notable exception of Peaker and Hunter, 2013 in Law (Journal of Housing Law).
} 
Lewis et al. 2015; Urry 2014; author 2015b; Waite 2009, Craig et al. 2015). To do so, we engage with debates around the concept of precarity, understood as the intersection of new conditions of heightened economic and political insecurity and their normalisation as specific 'structures of feelings' and subjectivities. Following Nancy Ettlinger, we deploy a framework that places particular emphasis 'on the everydayness of conditions that give rise to precarity' (2007, 321), but within a specifically spatial approach that insists on attending to the range of sites and socio-spatial relations through which precarity is produced and reproduced. At stake here, we believe, are important implications for how we come to think about and research precarity as spatially generative and co-constitutive of urban life.

This paper is organised into three parts. In the first section, we develop a theoretical framework for the study of PG that builds on and furthers existing scholarship on housing and geographies of work and life precarity in the Global North. The second section offers a detailed analysis of PG as a new and rapidly growing model of temporary property occupation at the intersection between housing and security, particularly in large urban centres. Drawing on in-depth interviews with current and former property guardians in London, the third section explores and discusses the rationales, conditions and geographies of living as a property guardian. We argue that the analysis of the different coping strategies and narratives mobilised by guardians in response to the multiple precarities that shape their lives and labours offers insights into the under-researched normalisation of life and work insecurity for often highly educated and relatively young urban professionals. In the end, we believe that these experiences are only the visible tip of a much wider spectrum of precarious geographies that are at the heart of contemporary forms of urbanisation. The lessons of PG thus derive less from strict typicality than from illumination - from the way it sheds light on the everyday nature of contemporary precarity. 


\section{Geographies of property guardianship at the intersection of housing and precarity}

As the feminist philosopher Judith Butler has recently argued, precarity is not a 'passing or episodic condition' (2015, xii). If anything, it represents, according to Butler, a key point of reference through which our present moment has been understood and felt, shaped and regulated. Precarity here names the experience of induced insecurity that is of a piece with contemporary neo-liberalism and this process, in Butler's view, acclimatises populations to forms of hopelessness and insecurity that are hard-wired into the very texture of contemporary governmental practices from the normalisation of temporary labour regimes to the decimation of social services 'in favour of entrepreneurial modalities supported by fierce ideologies of individual responsibility and the obligation to maximise one's own market value as the ultimate aim in life' (xiii). Butler also detects in these developments, a new understanding of precarity as a structure of feeling; what she describes as a 'heightened sense of expendability or disposability that is differentially distributed throughout society' (2011, 13).

As a number of scholars have argued, terms such as 'precarity,' 'precariousness' and 'precarisation' were first picked up and adopted by labour and social movements in Europe in the 1970s and have since become key placeholders for describing the emergence of new forms of flexible, contingent and irregular work (Lorey 2010; Molé 2010, 2011; Raunig 2010). At the same time, there has been considerable confusion over the precision of these terms especially given the historical ubiquity of precarious work for most workers around the world (Neilson and Rossiter 2008). The process of precarisation (Lorey 2015; author 1 2016) has nevertheless tended to converge around two primary meanings. First, as the production historical and otherwise - of deregulated privatised regimes characterised by short-term semi- 
permanent work. Second, as the normalisation of uncertainty and hypervigilance amongst worker-citizens no longer guaranteed the security of full employment (Molé 2010, 38). Precarity has therefore come to describe both a subject position and the affective embodiment of that position (author 2015b, 350). It references, in other words, a particular notion of work and the lived experience of that work as a form of intensifying anxiety and fragility. In the process of precarisation, new 'techniques of governing and subjectivation' (Lorey 2015, 2; see Raunig 2013) emerge that represent far more than the strict withdrawal of mechanisms and institutions that were central to the emergence of the Fordist welfare state in the Global North. At stake here, according to Isabell Lorey and many others, is the normalisation of precarious working and living conditions as both an art of government and as a source of intensifying exploitation (2015, 106; see also Lazzarato 2008; Lemke 2004; Lorey 2006).

While precarisation is, in this respect, hardly new and shaped by deeply sedimented patterns of insecurity, it is also, we argue, marked by its uneven spatialisation. As the anthropologist Anne Allison has recently suggested, precarity inhabits the 'loss of something that only certain countries, at certain historical periods, and certain workers ever had in the first place' $(2014,7)$. Allison's own focus is on Japan though others have drawn attention to the crystallisation of precarious living across the Global North as a condition 'that distinguishes this historical time' (Butler 2015, vii, emphasis added; Berlant 2011, 2016; Molé 2010, 2011; Muehlenbach 2012; Ross 2009; Standing 2011). Our own aim, in this context, is to further sharpen the geographical optic at work here and examine how cities themselves have become key laboratories for new social and economic practices associated with the production of precarious insecure lives (see author 2015b). To this end, we develop a framework that heeds Louise Waite's call for a 'critical geography of precarity' (2009) and that can be plotted, in our view, along two intersecting axes. The first revisits recent debates surrounding the 
potency of the concept of precarity as an analytical tool adequate to the theorising of work and life insecurity. The second re-centres ongoing attempts to spatialise the concept of precarity through a focus on the relationship between urbanisation and housing inequality. In sketching the conceptual contours of the 'precarious city' in this way, it is not our intention to advance a new understanding of city life that is all encompassing. Our motivations are more modest and shaped by a commitment to analysing the different ways in which employment and life insecurity, and new forms of insecure dwelling, are co-constitutive of increasingly precarious urban geographies. In what follows, we are not calling for the further plenary expansion of the term precarity, but rather insist on connecting the use of the term as an analytical tool to detailed qualitative research into the mutually constitutive relation between work precarity and precarious relations to place, and how this is experienced and narrated.

\section{Spatialising Precarity}

Recent studies of precarious life have tended to focus their sightlines on the rise of precarious employment in relation to urban living across advanced capitalist cities. Particular attention has been paid to the rise of casualisation and the concomitant decline of labour rights across different class and professional divides (see McDowell, Rootham and Hardgrove 2014; Neilson and Rossiter 2008; Ross 2009; Standing 2011). A number of studies have also explored the range of coping strategies and tactics adopted by workers as they negotiate the uncertainty of a labour market that forces them to repeatedly move in and out of precarious work (see Hardgrove, McDowell and Rootham 2014). In a case study of contemporary Italian workers, the anthropologist Noelle Molé (2010) has argued that workers anticipate precariousness in a state of 'heightened uncertainty' where the uncertainty of the labour market is internalised by the individual, who 'bears risk in exchange for labour market entrance' (see also Muehlenbach 2011). Beyond Italy, where new forms of workplace 
precarity have spawned a number of important studies, a small but growing body of geographical scholarship on the precarisation of labour regimes has also emerged (Dyer, McDowell and Batnitzky 2011; Fudge and Strauss 2013; Lewis et al. 2015). In the UK, the widespread shift towards workforce casualization, characterized by temporary and contract positions, has increasingly come to include graduate jobs. Scholars have noted how the shift has particularly affected young entrants in third-sector (Leonard et al. 2016) and creative and cultural industries (Gill and Pratt 2008; Neff et al. 2005), who experience a 'state of economic and social uncertainty' through a combination of low-pay, insecure part-time contracts and second-jobbing (Banks and Hesmondhalgh 2009, 423).

While some scholars have, unsurprisingly, advanced an understanding of precarity that is of a piece with conspicuously neo-liberal labour regimes, others have argued that it represents, in fact, 'something more than a position in the labour market' (Neilson and Rossiter 2005). An important and emerging literature has focused their attention on the interconnections between new forms of hyper-precarious labour and the deepening exploitation of migrant workers across the global North (Lewis et al. 2015; Reid-Musson 2014; Craig et al. 2015). Precarity, according to this view, is a direct product of the 'ongoing interplay of neo-liberal labour markets and highly restrictive immigration regimes' (Lewis et al. 2015, 582). Here the concepts of 'precarity' and 'precariousness' have been deployed as distinctive and different from related concepts of risk and vulnerability, in order to deepen our understanding of the condition of migrant labourers and refugees in terms of the interconnected questions of unfree labour and status. Along similar lines, Banki has proposed the term 'precarity of place' as distinct from labour precarity, to analyse the experiences of a subset of the precariat, 'that of non-citizens' $(2013,452)$ as exemplified by migrant labourers from Burma living in Thailand, whose multiple precarities encompass insecure legal status, labour and housing, as well as 
weakened social networks.

Other scholars, building on feminist material approaches to social reproduction and labour have explored the ways in which precarious work and living are mutually constitutive (see Strauss and Meehan 2015) while recent sociological studies have drawn particular attention to a form of double precarity marked by insecure employment and insecure housing (Desmond and Gershenson 2016, 47; Desmond 2015; Purser 2016). With an attention to multiple and intersecting insecurities, we seek to further these arguments by attending to the entanglements of work and life precarity, and their co-constitutive relationship with precarity of place. Precarisation, we argue, needs to be understood as a spatial process that generates and sustains a varied geography of insecurity, flexibility and temporariness, at once intensifying and normalising precarity. Returning to the spatial roots of the term and its original usage in English, both the adjective precarious and the noun precariousness refer to specific relations to land and space. The etymology comes from the classical Latin precārius: 'given as a favour, depending on the favour of another, (of property) held by tenancy at will, uncertain, doubtful, suppliant' [OED 2007, $3^{\text {rd }}$ edition] and usage in English language is attested as early as the first half of the $17^{\text {th }}$ century especially in connection with tenancies 'held or enjoyed by the favour of and at the pleasure of another person' (Ibid). While this original meaning as related to land rights is now rarely applied, it adds a specific spatial dimension to other current etymologies that stress the sense of obtaining something by prayer, entreaty or favour (Shukaitis and Figiel 2012).

\section{Urban precarity}

A spatial approach to the mutually constitutive relation of work, life and place precarity allows us to revisit current debates about emerging conditions of urban living and of urban 
housing in particular. The evolving housing crisis in cities in the Global North is a welldocumented phenomenon whose root causes predate but have been made more visible by the 2008 global financial crisis. Scholars have been returning to basic questions around housing and urbanisation (Harvey 2012, 2014) in order to recentre and reformulate our understanding of the current crisis (Aalbers and Christopher 2014a). While housing crises are recurrent elements in capitalist societies and speak to the centrality of housing within the complex circuitry of capitalist accumulation (Aalbers and Christopher 2014b), new avenues for research into precarious housing conditions have been outlined by literature drawing significant connections with debates surrounding the financialisation of everyday life (Craig 2015) as well as recent work on the role of housing in the implementation of what Jamie Peck has called a post-crisis regime of 'austerity urbanism' (Peck 2012).

Features of the current widespread housing crisis in Europe and North America include, on the one hand, an intensification of tenure insecurity and an increase in forced evictions (author 3 2016; Desmond 2016). They have also prompted, on the other hand, a rise in protest and new forms of organising, as well as the development of informal alternatives which have, of course, geographically specific histories and trajectories. In focusing on the situation in the UK, perhaps the most important facet of the current housing crisis is the increasingly widespread insecurity of tenure for individuals and households in rented accommodations, both across the social and the private rented sectors. Insecurity of tenure in the social rented sector has been analysed in relation to the rise of 'conditionalised temporary tenure' (Hodkinson and Robbins 2013) and the introduction of fixed-term 'flexible' tenancies in council housing and housing associations (London Tenants Federation 2011), which should be understood in the context of stock transfer from the public and third sector to the private, as well as of the rapid spreading of schemes that involve the redevelopment and demolition of 
formerly council housing (Fenton et al. 2013; Lees 2014; Watt 2009). While low-income groups eligible for social housing have been disproportionately affected by the recent housing crisis, for over a decade calls have been made to reconsider the traditional relationships between tenure and level of education. While university educated 'marginal professionals' have been shown to 'make use of a range of housing forms and tenures' (Watt 2005, 362), young graduates in precarious occupations in particular have been identified a significant demographic marginalised by the current housing system (Stephens 2012).

Within the uneven geographies of housing in the UK, the cardinal significance of London cannot be sufficiently stressed, both as an experimental testing site for emerging semi-legal housing practices, such as the so-called 'bed in sheds' phenomenon in London (London Councils 2012) and as a policy powerhouse (see Edwards 2016; Watt and Minton 2016). London occupies a unique role within a broader national housing crisis. As the centre of the economic recovery and employment growth, demand for affordable housing exceeds supply, which is, moreover, dominated by an unregulated Private Rented Sector (Kemp 2011). Furthermore, affordable housing provision in the capital has been further affected by the erosion of the policy category of 'affordable housing' in new built developments (London Tenants Federation 2011) and by the increasing privatisation (Watt, 2009) of the still relatively large public housing sector through processes of stock transfer, redevelopment and demolition (Fenton et al. 2013; Lees, 2014).

While it is our contention to firmly situate the emergence of PG as a form of unregulated, semi-formal housing, in the context of the growing shift of many housing practices from marginal to mainstream, we strongly believe that housing precarity cannot be studied on its own, and, in this paper, we propose a synthetic framework that builds on recent attempts to 
bring different geographical approaches to precarious work and precarious life into conversation (Strauss and Meehan 2005, 1). At stake here is a framework that tracks the coconstitution of precarious urbanisms and which builds on recent work on the 'geographies of precarity $^{2}$ by attending to a more expansive landscape of urban uncertainty and multiple vulnerabilities.

\section{Researching Property Guardianship}

In the following two sections we develop a spatial reading of the life and work precarity experienced by property guardians. Particular emphasis is placed on the economic, social and legal mechanisms that inform PG, as well on the rationale of guardians and the geographies of 'licensed living'. The first part of this section provides a detailed overview of the various forms of PG that have emerged in the United Kingdom since the early 2000s. We examine the specific legal and economic mechanisms that constitute PG as a new form of vacant property inhabitation that operates at the intersection between housing and security provision. Drawing on Freedom of Information (FOI) requests, interviews with founders of property guardian companies and a review of relevant industry reports, we argue that PG is a growing sector that has over the past five years developed into a spectrum of positions and forms of organisation between the private and the third sectors. In the second section, we hone in on the experience of being a property guardian in London drawing on thirty-two in-depth interviews with current and former property guardians undertaken over a three-year period (2011-2014).

All interviewees were or had been guardians with seven different organisations, of which four were for-profit property guardian companies, one a housing association, one a social

\footnotetext{
${ }^{2}$ See sessions organised on "Precarious Geographies" at the AAG Annual Meeting and at the RGSIBG Annual Conference in 2015.
} 
enterprise and one a cultural organisation providing 'live/work' space. ${ }^{3}$ To be considered for a guardianship, candidates need to provide up to three references, proof of sufficient savings or regular income during the three months prior to the application ${ }^{4}$, must not have a criminal record, children or pets; the application procedure also often includes a vetting interview. In addition, guardians are not officially permitted to use the property as their primary address. Such requirements evidently circumscribe the availability of PG to a limited section of the urban population. In fact, the majority of guardians interviewed belonged to a relatively homogenous group: they were university-educated, British or EU citizens, within the age range of early 20 s to early 40 s, either in work or education or both, often part-time or intermittently; they generally self-identified as middle-class and as geographically and professionally mobile. When asked about their understanding of guardians' profiles, interviewees indicated that our interview sample was largely representative of the wider demographic of PG.

We acknowledge, however, that our methodology presents potential limitations with regards to the breadth and diversity of experiences. Recruitment of participants was affected by guardians' anxiety about losing their homes due to a clause in the licence agreement that forbids them from talking about their living conditions to the media. It was therefore felt that a relationship of trust needed to be in place in order to carry out the investigation and interviewees were thus approached through snowballing and personal networks of two of the researchers, both of whom were young university-educated women. Within this sample, care was taken to explore diversity of experience through interviewing current and past guardians, as well as through including individuals who lived as property guardians for different lengths

\footnotetext{
${ }^{3}$ Nearly half of interviewees had lived at one point with one of the largest for-profit PG companies. ${ }^{4}$ In guardians' experiences, the degree of scrutiny about regular income varied greatly across PG companies.
} 
of time. The second half of the article draws in particular on in-depth interviews with eleven individuals who have been property guardians for a minimum of three years in an attempt to develop a more longitudinal understanding of what we conceptualise as the co-constitutive life, place and work precarity of PG living. Interviewees' names, their places of residence and the companies for which they acted as guardians have been fully anonymised.

\section{The rise of property guardianship}

The model of PG as a form of low-cost temporary housing in vacant buildings originated in the Netherlands in the early 1990s and became, over the following decade, an established form of affordable dwelling for low-income individuals. The model expanded particularly during the mid-2000s, coinciding with the demise of residential and eventual criminalisation of squatting in 2010. In the Netherlands, PG is known as Anti-Kraak (Dutch: anti-squatting) and it is officially considered an appropriate alternative and preventative to squatting and vacant property (Buchholtz 2009). There are around fifty property guardian companies operating in the Netherlands alone (Bond Precaire Woonvormen 2014). PG schemes are also currently present in Belgium, Ireland, France and Germany (author 2 2012; Heijkamp 2010).

PG companies position themselves as intermediaries between two different groups and sets of demands: property owners and managers looking for low cost security options and individuals looking for affordable living space. Legally, the relationship is set through two different agreements: an authorisation agreement (owner or manager) and a temporary occupation licence (guardian) (see Figure 1). To preserve the company's role as intermediary, the licence forbids guardians to engage in direct communication with the property owners or managers.

Figure 1 Diagram showing PG companies as intermediaries. Source: authors. 
Most commonly, both property owners or managers and guardians pay the property guardian companies for their intermediary services, although smaller companies may offer their service to owners for free or on a trial basis. Guardians pay a monthly 'licence fee' (in lieu of rent) to access the dwellings. Companies may also ask for administration fees, returnable deposits and a one-time fee to provide security equipment such as fire safety packs. Although the guardians' monthly fees are usually below market rent for a similarly located dwelling, critics of the scheme such as the British campaign group SQUASH (Squatters' Action for Secure Housing) have criticised the economics of this agreement as a double income for the companies, to the detriment of the guardians (Boehnert 2012).

In the UK, PG can be seen as a continuation of the Dutch model as well as developing locally specific formats. Our research indicates that there are at least 32 registered organisations that offer live-in property guardians as a vacant property security service (author 2, 2012). The Dutch-originated businesses, Camelot and Ad Hoc, dominate the market. Their first offices in the United Kingdom opened in 2001 and 2006 respectively in London; Camelot has six UK offices at the time of writing, Ad Hoc ten, their newest being in Leeds and Liverpool. Security firm Orbis estimated that 4000 individuals live as guardians in the UK $(2014,7)$ but given the rapid growth of the sector, and the fragmented information in the public domain, the overall figure is likely to be significantly higher. Desk-based research has shown a rapid growth of PG in the UK since the global financial crisis of 2007/8, with at least 22 out of the 32 companies being founded since 2009. PG companies have enjoyed growing public currency and acceptance, with large PG companies regularly attending international real estate investment fairs such as MIPIM (Le Marché International des Professionnels de l'Immobilier, see Bond Precaire Woonvormen 2014), where they promote their services to private and public property owners. As will be discussed further on, PG companies offer 
security for a wide array of vacant properties, from residential to commercial, and have been regularly deployed by local governments to secure buildings in public ownership, with UK national government agencies promoting or directly supporting 'live-in guardians' in the context of public housing demolition and redevelopment (Homes and Communities Agency 2011).

In terms of typology of PG companies, as illustrated in Table 1, they can be grouped into three main categories. We have categorised companies as type 1 when the provision of live-in security constitutes their main profit-making activity; this typology comprises both established and newly founded companies. Type 2 companies are PG organisations that present themselves as 'ethical' alternatives; they are usually aimed at volunteers and individuals working in the arts and creative sectors and are sometimes registered as nonprofit. Type 3 includes security companies that offer PG as a minor part of a wider portfolio of security options for property owners; these are all large, for profit organisations. According to recent industry reports, $\mathrm{PG}$ is projected to grow in the future as a 'professionalised' section of the sector (Orbis 2014) as well as a growing 'niche' market for 'ethical' social enterprise organisations with quite different emphasis.

Table 1 Companies offering property guardians in the UK, ordered by date of establishment (when known). Sources: authors.

In terms of their geographies, DEX Property Management, Camelot and AdHoc, marked with an asterisk in the table, were founded in the Netherlands and operate internationally. Around two-thirds of UK-only companies appear to only have a single office in London, and thirtysix per cent appear to be exclusively operating in the capital, reinforcing the significance and uniqueness of London's both as a site of heightened property sale and development and as 
affected by undersupply of affordable housing. While such tables can be useful to outline similarities and differences between companies, in practice it would be more accurate to talk about a continuum of forms of guardianship; from paying to non-paying guardians, to paid 'caretakers' and security guards, operating within the legal grey area at the intersection of housing and security. Such a complex framework requires an understanding of the ways in which companies and schemes actually operate on the ground and their implication for the emergence of forms of precarious urban subjectivities, as explored in the following part of the paper.

\section{Becoming a Property Guardian}

Want to live somewhere unusual and meet great people? Live the Ad Hoc way.

(Ad Hoc 2015)

While understanding the socio-legal-material infrastructure of PG is important, living as a property guardian cannot be simply approached as the management of property security and housing insecurity. PG, we argue, is a 'form-of-life' which presupposes a process of becoming a guardian, constituting a specific subjectivity by promoting and establishing precarious forms of relating to home and to the city, while at the same time being coconstitutive of wider forms of precarity of life and labour. To develop this thesis we draw on the everyday geographies of living a property guardian in London. We do so by outlining three interconnected dimensions of PG as a form of precarious urban living: an analysis of the rationales, requirements and processes of applying for a property; the relationship between labour and of home; and, finally, the issue of spatial flexibility expressed in city-wide mobility and the use of space.

Social networks, requirements and entrepreneurialism

Guardians are often well integrated into urban social and professional networks, which are 
often key to their discovering and applying for PG. As explained by a former guardian, such networks were initially central to the establishment of PG as companies could 'capitalise on the interpersonal relationships of creative types' (Interview, April 2011) relying on 'word-ofmouth' to recruit guardians. The initial popularity of the scheme among workers in the creative and third sectors can be explained both by the notoriously low paid and precarious working conditions of these industries (Merkel 2015), but also by their 'networked' nature, in which access to work is often reliant on personal and professional networks (McRobbie 2002). Guardians who joined the scheme after 2012 were more likely to discover the option through online searches or newspaper articles; a fact that that correlates with findings about the surge of newly registered companies and the wider public acceptance of the scheme. The vast majority of recent guardians, however, still decided to apply only after having being advised by other guardians in their inner or wider social and professional circles, evidence that social and professional networks play a significant role in accessing housing arrangements through PG.

Becoming a guardian in central London can be a long and highly competitive process. As early as 2010, one of the largest PG companies claimed to have received 2,000 applicants in four days for 15 apartments in a central London borough (Camelot 2010). The waiting time varies vastly depending on the size of the company and on its business model. Larger companies openly state that they do not keep waiting lists, while guardian candidates with smaller PG companies can wait for several months before being offered a property (Interview, January 2014). The uncertain temporality of waiting contrasts with a demand for availability at short notice once a property becomes available, with some companies requesting candidates to attend viewings on the same day. At the viewing, prospective guardians often reported being pressured to inspect and decide whether to take a room within minutes, at the 
risk of losing the option. Piero, a part-time text editor, freelance musician and long-term guardian in his mid-30s described the experience of viewing a property as 'a rat race' in which candidates 'are very well aware that if [they] don't make [their] mind up very soon, other people will take the rooms'. Another guardian described how the viewing process itself acted as a filter for perspective guardians:

[the officers from the PG company] turn up really late so there's people milling around, so that when they arrive there, they're really ruthless, they go around numbering the rooms, like, this will be number 1, number 2, who wants it? Who wants it? And they'll try and fill them up really quickly [...] I've recommended a lot of friends to do it and they've been put off by that. You have to be really up for it, you have to be like, yep, cool, I want to do it. Yeah I'll pay you, yeah, I'll move in tomorrow (Jenny, late 20s, part-time architect).

The waiting time, on-demand availability and the pressure experienced by guardians when viewing a property can be seen as an important component of the process of becoming a guardian. Prospective guardians have to be 'really up for it' and able to endure the 'rat race': a self-narrative that highlights difficulties while simultaneously celebrating a spirit of adaptability, alertness and readiness in an unfamiliar environment. Such expectations have become increasingly commonplace within a range of precarious workplaces (food delivery, taxi driving, warehouse logistics, etc) and point to the internalisation of an ethos of entrepreneurship and personal responsibility within a much wider 'on-demand' economy (Malin and Chandler, forthcoming).

\section{Precarious work, flexible home}

The close relationship between flexibility and insecurity in housing and work-related life choices is a key recurring theme in our interviews. With regular income as a prerequisite to becoming a guardian, the majority of interviewees were in employment. For most, entering PG coincided with their move to London as young graduates or to pursue further studying. As 
an affordable alternative to renting (AdHoc 2015), PG has become for many the only viable option for moving to the capital. This was the case for Lucy, a young guardian in her midtwenties originally from the North East of England who applied to become a guardian immediately after being accepted on a Masters course. After waiting for three months to be contacted, and with the starting date of her course approaching, she 'was getting worried because it would [have been] really difficult to pay rent at a normal London price' while living off her savings. Guardianship enabled others to remain in London and be available for work, which they needed to establish themselves professionally. As explained by Jenny:

I'm working in performance design, but it's really low pay and quite bitty, and I haven't got complete work in that, so I have a three-day a week job [but] I can't work more than three days and keep the theatre going, so I needed an affordable place to live so that I could only work part-time. Until theatre stuff becomes permanent, this is my only way of keeping a base in London. I could easily afford a place in [city outside London] but for some reason I feel like it might be beneficial to have a place here for London theatre work if it comes up.

Such accounts are not unusual. Several interviewees had decided to become guardians in order to work part-time, develop a practice in the creative or third sectors and still be able to live in London. According to Piero, guardians in music and the arts especially tended to live on 'this sort of poverty threshold where you have enough to have a decent living, and you spend enough time to do your own projects'. For some, the experience has been largely positive. In the words of Justine, a visual artist in her late 20 s, living as a guardian can be 'a very good career kick-starter' in sectors that require volunteering or long periods of intermittent, low-paid and unpaid work. As explained by Eleanor (late 20s, community worker and freelance researcher), many of her fellow guardians were musicians who 'wanted flexible short-term jobs so they could stop and start, go on tour [with their band]'. The flexibility of living arrangements thus corresponded to and fed on the requirements of job mobility and flexibility. In this context, presenting of PG as a positive enabler for professional careers is grounded in a widespread acceptance of job insecurity in many creative sectors and 
of what the founder of a Type 2 'ethical' PG company defined a 'new, more precarious way of living'. The 'new, more precarious way of living' is narrated by guardians as simultaneously a matter of personal choice and as systemic, evidencing a process of 'self-precarization' (Lorey 2006) for young entrants in creative and third-sector professions.

While the notion of living in an insecure home as 'a career kick-starter' reproduce the narrative of periods of hardship followed by success and job security, typical of the creative sectors, other guardians are more sceptical. As admitted by Liam, a guardian in his mid 20s doing two temporary part-time admin jobs to save for an MA, guardianship is certainly not the ideal housing situation, but resignation to it draws on a widespread feeling, among university graduates, of being trapped within cycles of intensifying precarisation, leading to a sense of powerlessness:

[W] 're having to work harder and live less securely, and accept the fact that there actually aren't any rights to work and nobody's particularly geared towards changing that, I guess. We're so busy all the time, it's harder to do that kind of thing.

Insecure creative career and precarious housing arrangements thus appear mutually constitutive, reinforcing each other in the manufacturing of new forms of flexible urban subjectivities, particularly in highly prized centres of higher education and professional development such as London.

\section{Spatial flexibility of 'licensed living'}

...the key to being a property guardian, you've got to be so flexible in every respect.

(Louise, 26, part-time charity worker)

Beyond work, flexibility 'in every respect' also includes guardians' relationship to the space and its use. The properties occupied by guardians in London are widely different, depending on the area of the city, individual borough and neighbourhoods, and on whether the property 
owner is private or public. The fast turnover at point of application and the possibility of losing their home in two weeks, is often described as 'stressful', also due to the unpredictability of available properties, which might be inconveniently located, for example too distant from places of work and study, or within badly-lit and unsafe green areas, industrial estates or semi-abandoned and dilapidated council estates. A large number of guardians interviewed, however, claimed that they would consider accepting a property 'anywhere in Greater London' (Piero); for others, the unpredictability and relative lack of choice was a positive element, as it was 'interesting to see parts of London in that way', particularly those that would be otherwise inaccessible, such as affluent inner city and suburban areas (Judith, early 30s, part-time shop assistant and freelance sound engineer). Guardians' attitude to moving frequently between different buildings, boroughs and neighbourhoods of the city at times drew on narratives of exceptionality and 'neobohemian' subjectivation (Lloyd 2004) with some even taking pride in their mobility by claiming, in the words of a former guardian, to belong to 'quite a special species in London - that can [just be] dropped in' (Clemoes 2014) wherever and whenever.

Among non-residential properties, guardians may live in former office buildings, town halls, libraries, fire stations, adult education facilities and schools, hospitals and care units, warehouses and even an abattoir; all of which required a high degree of adaptability, particularly if the building did not originally possess living facilities, such as a heating system, cooking or sanitary services. While PG living was lacking some comforts, guardians had often experienced poorer living conditions in more expensive, smaller, and short-term private rented accommodations, which made guardianship a better living option for the majority of interviewees. Moreover, many understood their spatial precarity as inevitable in a city like London. Widespread resignation, for some, was evidence that 'living in a big city 
like London produces a certain subjectivity where you're like, I'm so lucky to have somewhere to live at all' (Liam). The temporary and instrumental relationship to the city of many young graduates was also mentioned as influential in the general acceptance of the constant uprooting experienced through PG. As commented by Piero, very few expect to be able to root themselves in an area: 'London is [...] a place where few people stay for more than 10 years. So it's like a transit. People do a bit of education, career, whatever. Then you realise you've done that for a time [and] you find a place that suits your values better'.

Flexibility is also a key attribute of the relationship of guardians to the buildings as 'licensed living' is conditional on regulations and codes of behaviour set out by the licence agreement. While different companies have different 'codes of conduct', broad similarities regard fire regulations, including the prohibition to smoke on the premises, and restrictions to the use of electric equipment such as electric heaters and toasters. When rules are breached, guardians may receive fines, lose of part of the initial deposit or even have their licence immediately terminated. In case of breaches, companies may send 'threatening' emails to all guardians in a property, which for some created 'this aura of fear where you always have to be afraid that they are going to get you, somehow, that you are going to do something that is prohibited by the licence agreement' (Piero).

Compliance with the code of conduct is usually monitored by unannounced inspections. In contrast to a tenancy agreement, a licence does not grant exclusive possession of the property, which results in the PG companies being able to access living spaces at all times. Inspections are usually marked by 'inspection cards' with notes and warnings, which contribute to creating awareness among guardians of regular surveillance. George, a freelance designer in his early 30s, explains his ambivalent feelings about finding inspection cards in his room: 
That's the only slight uuuuhm thing about [PG]. It's only a little card but it does remind you [...] you never know when they are coming, so it's not like I clean especially [...] but it's just like, when my girlfriend is over, you want to make sure that the pack of condom is put away and not left out, things that might embarrass them, like dirty underwear.

Like George, most guardians expressed a general sense of acceptance about the lack of privacy in their living spaces, with some experiencing surveillance as a form of individual and collective boundary negotiation. Emma, a visual artist in her late 20s doing casual work for a catering agency, explains that inspections are marked by arbitrariness and inconsistencies. Just as guardians are fined for minor issues such as propping open a fire door in a communal area, others may not be fined at all for graver misdemeanours, and the situation 'can be very exasperating' as ‘you don't know how much you can push on either boundary, you don't even know if the boundaries are there'. Others described the emergence of forms of cooperation among guardians living in the same property to alert about inspections and support each other in hiding potential breaches (Julia, mid-30s, teacher on a temporary contract).

Perhaps to prevent the possibility of cooperation, some companies also rely on overt and covert surveillance by selected guardians within properties. Recently, at least two companies have formalised this role by appointing 'Head Guardians' in properties where several guardians live; one of them explained on its websites that the role may involve 'tak[ing] an active part in securing the building, above-and-beyond those outlined in your induction packages. [...] Obviously, the more responsibilities you adopt, the more favourable your accommodation costs will become ${ }^{, 5}$, which in practice often means first choice of buildings and rooms and a discount on the monthly fee. The flexibility and adaptability demanded of guardians in their relationship to urban space as well as to the individual properties thus

\footnotetext{
${ }^{5}$ Published on the 'Secure Guardians Ltd' website (2014), no longer trading as a subsidiary of Secure Foundations (Norwich) Ltd.
} 
combines a sense of exceptionality with a widespread resignation to precarious and low quality accommodation available, and a general acceptance of work and life transience in the capital. In controlling spatial use, PG companies operate through surveillance techniques paired with an individualising distinction between deserving and undeserving guardians within a framework of punishment and rewards that echoes similar practices in precarious work relations (Carls 2007).

\section{Conceptualising precarious geographies of work and housing}

In this paper we have argued for the need to address the spatialisation of precarity beyond questions of labour and to examine how the city has become a key laboratory for emerging geographies of flexible insecure living. More specifically, we have explored the recent growth of PG in the United Kingdom as a highly symptomatic expression of wider forms and patterns of urban precarity. At the heart of this paper is a thick description of the everyday experiences of current and prospective guardians that highlights the emergence of PG as a form of lowcost housing through which multiple precarities are produced and experienced. The paper focuses, in particular, on the spatialisation of labour and life insecurity and the paradoxical links - most notably in London - between a guardian's geographical proximity to centres of professional development and work and the unaffordable conditions that increasingly characterise their life in the capital as many struggle on intermittent, part-time and low-paid work. Housing flexibility through PG is experienced, we argue, in terms that are mutually constitutive of the on-going casualisation of professional work, particularly in creative and third sector organisations. The need to be available and ready to move in and out of properties is paralleled by and feeds on a similar imperative in the world of professional employment, so that the uncertainty and insecurity of entrance into the world of work becomes intimately 
related to housing which has the same attributes. To therefore return to Molé's (2010) definition of precarity, property guardians simultaneously bear risk for labour market entrance and for housing market entrance, at a point when both are increasingly characterised by insecurity.

In acknowledging the profound social, economic and legal differences between the hyperprecarious subjects discussed by Banki (2013), Lewis et al. (2015) and the largely middleclass university-educated cohort that principally makes use of PG schemes in London, we nonetheless argue for the need to approach the rise of property guardianship not as an exception in contemporary urban housing and labour dynamics, but as a symptom of more widespread and less visible experiences of 'precarity of place' in cities in the global North. An attention to the types of properties and the forms of inhabitation is key. Studying property guardianship sheds critical light on individual and collective practices of negotiation and adaptation that are of a piece with wider logics of urban dispossession and displacement. This is particularly the case as a large portion of the vacant buildings being secured belong to public institutions and are vacant because of entrenched processes of privatisation and sale of public sector assets, such as libraries, town halls, schools and health facilities (Whitfield 2010), and, importantly, of council housing (Hodkinson and Essen 2015), a process exacerbated by public budget reduction measures introduced by the UK Coalition Government (2010-15) (Whitfield, 2012).

If the experience of PG offers important insights into emergent precarious geographies, it does so by foregrounding the spatial significance of the normalisation of flexible neoliberal subjectivities where the demands and risks of the property security market and precarious employment are internalised through forms of self-governance (Lorey 2006; 2015). Returning 
to Nancy Ettlinger's definition of precarity as 'a condition of vulnerability relative to contingency and the inability to predict' $(2007,320)$, through the study of PG we have examined the interconnected ways in which 'precarity of place' in the Global North includes a range of conditions of vulnerability which are experienced as 'ordinary' and which inform the emergence of new precarious urban subjectivities. What is, we believe, especially remarkable and politically significant about the experience of PG is the guardians' acceptance of their multiple insecurities as an inevitable condition of contemporary urban life. As numerous scholars of the 'flexible' workplace have argued, the study of PG highlights the production of precarious urban subjectivities in which the acceptance of widespread precarity not only borders on resignation to the very condition of precariousness itself, it also appears to present the requirements of flexibility and adaptability as an enabling and liberating choice (see Cockayne, 2016; Gill and Pratt, 2008; Neff, 2012). The glamorisation of alternative forms of urban living as markers of elective marginality has led to forms of self-identification that shun ideas of victimhood in favour of imaginaries of resourcefulness and expediency under adverse circumstances. The mobilisation of the notion of flexibility in relation to the city, the buildings and to the use of spaces themselves belongs, we argue, to the internalisation of a neoliberal discourse of personal responsibility and adaptability, particularly in times of work and housing 'crisis'. In is with this context ultimately in mind that we have sought to make a theoretical and empirical contribution to emerging geographical scholarship on precarity and precariousness with the aim of stimulating a wider research agenda in the study of the interrelation between new models of insecure housing, precarious life and work and the normalisation of flexibility and uncertainty as a mode of urban governance. 


\section{References}

Aalbers M and Christophers B 2014a Centering housing in political economy Housing, Theory and Society 31 373-394

Aalbers M and Christophers B 2014b The Housing Question under Capitalist Political Economies Housing, Theory and Society 31 422-428

AdHoc 2015 (http://www.adhocproperty.co.uk/property-guardians/living-the-ad-hoc-way/) Accessed 15 February 2015

Allison A 2013 Precarious Japan Duke University Press, Durham, NC

Banki S 2013 Precarity of place: a complement to the growing precariat literature Global Discourse 3 450-463

Banks M and Hesmondhalgh D 2009 Looking for Work in Creative Industries Policy. International Journal of Cultural Policy 15(4) 415-430

Berlant L 2011 Cruel Optimism Duke University Press, Durham, NC

Boehnert J 2012 Council pays $£ 440,000$ so security firm can exploit tenants SQUASH (Squatters' Action for Secure Homes) website

(http://www.squashcampaign.org/2012/04/council-pays-440000-so-security-firm-can-treatexploit-tenants/) Accessed 12 August 2012

Bond Precaire Woonvormen 2014 Anti-MIPIM statement (http://www.reclaimingspaces.org/2014/03/antimpim-bpw-against-anti-squat-and-temporary-rent-contracts/) Accessed 20 September 2015

Butler J 2011 For and against precarity Tidal: Journal of Occupy Theory 1 12-13

Butler J 2015 Foreword in Lorey I State of Insecurity: Government of the Precarious Verso, London

Camelot Property Management Ltd 2010 Vacant Property Workshop. Presentation $21^{\text {st }}$ April 2010, Walsall

Camelot Property Management Ltd 2014 (http://uk.cameloteurope.com/73/2/vicky-andjane/vicky-and-jane-in-a-school.html) Accessed 11 July 2015

Camelot Property Management Ltd 2015 Press release 4 August 2015

(http://uk.cameloteurope.com/4/0/news/guardianship-provides-new-low-cost-housing- 
option.html\&nid=1415) Accessed 13 July 2015

Cockayne D 2016 Entrepreneurial affect: attachment to work practice in San Francisco's digital media sector Environment and Planning D: Society and Space 34, 456-473

Craig G, Waite L, Lewis $\mathbf{H}$ and Skrivankova K eds 2015.Vulnerability, Exploitation and Migrants: Insecure Work in a Global Economy Palgrave MacMillan, London

Desmond M 2016 Eviction: Poverty and Profit in the American City Allen Lane. London

Desmond M, Gershenson C Housing and employment insecurity among the working poor Social Problems 63 46-67

Dorling D 2014 All That is Solid: How the Great Housing Disaster Defines our Times Allen Lane, London

Carls K 2007 Affective Labour in Milanese Large Scale Retailing: Labour Control and Employees' Coping Strategies ephemera 7 46-59

Edwards M 2016 The housing crisis and London City 20 222-237

England C 2015 Property guardians: a solution to the UK's housing crisis? The Guardian $24^{\text {th }}$ March 2015

Ettlinger N 2007 Precarity unbound Alternatives 32 319-340

Fenton A, Lupton R, Arrundale R, \& Tunstall R 2013 Public housing, commodification, and rights to the city: The US and England compared Cities 35 373-378

Fudge and Straus K 2013 Temporary Work, Agencies, and Unfree Labour: Insecurity in the New World of Work Routledge, New York

Gill R and Pratt A 2008 In the social factory?: Immaterial labour, precariousness and cultural work Theory, Culture and Society 25 1-30

Hardgrove A, McDowell L, Rootham E 2015 Precarious lives, precarious labour: family support and young men's transitions to work in the UK Journal of Youth Studies 18 10571076

Harvey D 2012 Rebel Cities: From the Right to the City to the Urban Revolution Verso, London

Harvey D 2014 Seventeen Contradictions and the End of Capitalism Profile Books, London 
Heijkamp, A 2010 ‘Carefree Vacant Property’ (Dutch: Leegstand Zonder Zorgen), documentary film (http://vimeo.com/9649993) Accessed 27 October 2013

Hodkinson S 2012 The return of the housing question Ephemera: Theory \& Politics in Organization 12 423-444

Hodkinson S and Robbins G 2013 The return of class war conservatism? Housing under the UK Coalition Government Critical Social Policy 33 57-77

Hodkinson S and Essen C 2015. Grounding accumulation by dispossession in everyday life: The unjust geographies of urban regeneration under the private finance initiative International Journal of Law in the Built Environment 7(1) 72-91

Homes and Communities Agency 2011 Empty Homes Toolkit London, HCA

Hunter C and Peaker G 2012 Who Guards the Guardians Journal of Housing Law 297 (16)

Kemp P A 2011 Low-income tenants in the private rental housing market Housing Studies 26 1019-1034

Lazzarato M 2008 Le gouvernement des inégalités. Critique de l'insécuritee néolibérale. Éditions Amsterdam, Paris

Lemke T 2001 'The Birth of Bio-Politics' - Michel Foucault's Lecture at the Collège de France on Neo-Liberal Governmentality Economy and Society 30 190-207

Leonard P, Halford, S and Bruce K 2016 'The New Degree?'Constructing internships in the third sector Sociology 50(2) 383-399

Lewis H, Dwyer P, Hodkinson S, \& Waite L 2015 Hyper-precarious lives: migrants, work and forced labour in the Global North Progress in Human Geography 39 580-600

Lorey I 2006 Governmentality and Self-Precarization. On the normalization of cultural producers Transversal (http://eipcp.net/transversal/1106/lorey/en) accessed 22 June 2015

Lorey I 2010 Becoming common: precarization as political constituting E-flux (http://www.e-flux.com/journal/becoming-common-precarization-as-political-constituting/) Accessed 10 September 2015

Lorey I 2015 State of Insecurity: Government of the Precarious Verso, London

London Councils 2012 London Councils response to government's 'beds in sheds' announcement (http://www.londoncouncils.gov.uk/news/current/pressdetail.htm?pk=1517) Accessed 5 September 2015 
London Tenants Federation 2011 The Affordable Housing Con - Report LTF, London

McDowell L, Rootham E, Hardgrove A 2014 Precarious work, protest masculinity and communal regulation: South Asian young men in Luton, UK Work, Employment, and Society $28847-864$

McRobbie A 2002 Clubs to companies: notes on the decline of political culture in speeded up creative worlds Cultural Studies 16 516-531

Malin B, Chander C forthcoming Free to work anxiously: splintering precarity among drivers for Uber and Lyft Communications, Culture and Critique

Merkel J 2015 Coworking in the city ephemera: theory \& politics in organization 15121 139

Meyer H 2013 Sky-high rent? Why not get a home on the cheap and live like a lord, The Observer, $1^{\text {st }}$ September 2013.

Molé N 2010 Living it on the skin: Italian states, working illness American Ethnologist 35 $189-210$

Molé N 2011 Labor Disorders in Neoliberal Italy: Mobbing, Well-Being and the Workplace. Bloomington, IN, Indiana University Press.

Muehlebach A 2011 On affective labour in post-fordist Italy Cultural Anthropology 26 59-82

Muehlebach A 2012 On precariousness and the ethical imagination American Anthropologist $115297-311$

Neff G 2012 Venture Labor: Work and the Burden of Risk in Innovative Industries. Cambridge, MA, MIT Press

Neff G, Wissinger E, and Zukin S 2005 Entrepreneurial labour among cultural producers: 'cool' jobs in 'hot' industries Social Semiotics 15 307-334

Neilson B and Rossiter N 2005 From precarity to precariousness and back again: labour, life and unstable networks The Fibreculture Journal 5 (http://five.fibreculturejournal.org/fcj-022from-precarity-to-precariousness-and-back-again-labour-life-and-unstable-networks/) Accessed 12 April 2013

Neilson B and Rossiter N 2008 Precarity as a political concept, or, fordism as exception Theory, Culture and Society 25 51-72 
Norwood G 2010 Property guardian schemes offer quirky homes at low rents. But not for long, The Observer, $10^{\text {th }}$ January 2010

Orbis, 2014 White Paper on property guardians (http://www.orbisprotect.com/discover-newguardians-service-download-white-paper/) Accessed 27 June 2014

Peaker, G Quis custodiet ipsos custodes? Nearly legal blog 22 November 2012 (http://nearlylegal.co.uk/2012/11/quis-custodiet-ipsos-custodes/) Accessed 22 September 2015

Peck, J 2012 Austerity urbanism: American cities under extreme economy City 16(6) 626655

Pendall R, Theodos B \& Franks K 2012 Vulnerable people, precarious housing, and regional resilience: an exploratory analysis Housing Policy Debate 22 271-296

Property Guardians Research Collective 2014 The temporary home: Live-in Guardians in the Neoliberal City New Left Project

(http://www.newleftproject.org/index.php/site/article_comments/the_temporary_home_live_i $\mathrm{n} \_$guardians_in_the_neoliberal_city) Accessed 12 October 2015

Purser G 2016 The circle of dispossession: evicting the urban poor in Baltimore Critical Sociology 42 393-415.

Reid-Musson E 2014 Historicizing precarity: A labour geography of 'transient' migrant workers in Ontario tobacco Geoforum 56 161-171

Ross A 2009 Nice Work If You Can Get It: Life and Labor in Precarious Times New York University Press, New York

Shukaitis S and Figiel J 2012 Editorial Subjectivity 5 1-14

Stephens M 2014 What Will the Housing Market Look Like in 2040? Report. Joseph Rowtree Foundation, London

Stewart K 2012 Precarity's forms Cultural Anthropology 27, 518-525

Strauss K, Meehan K eds 2015 Precarious Worlds: Contested Geographies of Social Reproduction University of Georgia Press, Athens, GA

Urry G 2014 Neither presencing nor absencing: the stagnation of sensing-towards-presence in the call centre Transactions of the Institute of British Geographers 39 36-37

Wainwright O 2014 Wayne Hemingway's 'pop-up' plan sounds the death knell for the 
legendary Balfron Tower The Guardian $26^{\text {th }}$ September 2014

Waite L 2009 A place and space for a critical geography of precarity? Geography Compass 3 412-433

Watt P 2005 Housing histories and fragmented middle-class careers: the case of marginal professionals in London council housing Housing Studies 20 359-381

Watt P 2009 Housing stock transfers, regeneration and state-led gentrification in London Urban Policy and Research 27 229-24

Watt P, Minton A 2016 London's housing crisis and its activisms City 20 204-221

Whitfield D 2012 In Place of Austerity: Reconstructing the economy, state and public services Spokesman Books, Nottingham

Whitfield D 2010 Global Auction of Public Assets: Public sector alternatives to the infrastructure market and Public Private Partnerships Spokesman Books, Nottingham 
Figure 1 Diagram showing PG companies as intermediaries. Source: authors. $194 \times 132 \mathrm{~mm}(300 \times 300$ DPI $)$ 


\begin{tabular}{|c|c|c|c|c|c|}
\hline Organisation & TYPE & Founded & No. of offices & Office Locations & Property Locations \\
\hline Ambika Security & & \begin{tabular}{l|l}
1988 \\
\end{tabular} & 1 & London & UK \\
\hline * DEX Property Management & & 11999 & 1 & London & \\
\hline Gallowglass Security & & 31090 & & Edinburgh and W. Yorks & UK and abroad \\
\hline * Camelot UK & & 12001 & 6 & $\begin{array}{l}\text { London, Manchester, Birmingham, Glasgow, Bristol, } \\
\text { Leeds }\end{array}$ & UK \\
\hline *Ad Hoc UK & & 12006 & 10 & $\begin{array}{l}\text { London/SE, Woolwich, Birmingham, York, Liverpool, } \\
\text { Bristol, Glasgow, Peterborough, Cardiff, Newcastle }\end{array}$ & UK \\
\hline Newbould Guardians Ltd & & 12009 & 1 & London & London \\
\hline Live-In Guardians & & 12009 & 1 & London & \\
\hline Minae Property & & 12009 & 1 & Manchester & UK esp Mids \\
\hline Property Guardians & & 12009 & & London & UK - cities \\
\hline Guardians of London & & 12011 & 1 & London & London \\
\hline Global Guardians Management Ltd & & 12011 & 1 & London (North) & London \\
\hline City Guardians & & \begin{tabular}{l|l}
12011 \\
\end{tabular} & & London & London \\
\hline Dot Dot Dot property & & 22011 & 1 & London & $\begin{array}{l}\text { London, Cambridge, } \\
\text { S.England }\end{array}$ \\
\hline Plage Property & & 12012 & 1 & London & \\
\hline GPP - Guardian Property Protection & & 12012 & & London & UK \\
\hline Property Guardians in Cooperation & & 22012 & & London & London \\
\hline Blue Door Property Guardians & & 12013 & & London & London \\
\hline Intuitive Guardians & & 12014 & & Brighton and Hove & Brighton and Hove \\
\hline Cerberus Property Guardians & & 12014 & & London (South) & London \\
\hline Acorn Guardians & & 22014 & & London, Bristol, Brighton & \\
\hline Orbis & & 32014 & & & Uk-wide \\
\hline Eddisons & & 32014 & & & \\
\hline Secure Guardians & & 12012 ? & & London & London, Kent, Suffolk \\
\hline Grandploy & & 12013 ? & 1 & London & London \\
\hline Art Guard & & 22015 ? & & London (East) & London \\
\hline Violet Guardians & & $22015 ?$ & & London (South) & London \\
\hline Umbrella Guardians & & 1 & 1 & London & London \\
\hline London Caretakers Ltd & & 3 & & London & London \\
\hline Clearway Security & & 3 & & & \\
\hline Oaksure Security & & 3 & & London & \\
\hline VPS Specialists & & 3 & & & \\
\hline
\end{tabular}

Table 1 Companies offering property guardianship in the UK, ordered by date of establishment (when known). Sources: authors.

$222 \times 171 \mathrm{~mm}(300 \times 300$ DPI $)$ 